\title{
Efficacy and safety of standard and low dose ticagrelor versus clopidogrel in east AsianPatients with chronic total occlusion undergoing percutaneous coronary intervention: a single center retrospective study
}

Yong Wang, Hong-wei Zhao, Cheng-fu Wang, Xiao-jiao Zhang, Jie Tao, Chun-sheng Cui, Qing-kun Meng, Yu Zhu, De-feng Luo, Ai-jie Hou* and Bo Luan* ${ }^{*}$

\begin{abstract}
Background: Patients with coronary chronic total occlusion (CTO) require effective antiplatelet therapy after percutaneous coronary intervention (PCI). Ticagrelor has more pronounced platelet inhibition than clopidogrel. However, the most appropriate dose of ticagrelor in East Asian populations remains unclear.

Method: We compared ticagrelor $(180 \mathrm{mg}$ loading dose, $90 \mathrm{mg}$ twice daily thereafter and $120 \mathrm{mg}$ loading dose, $60 \mathrm{mg}$ twice daily thereafter) and clopidogrel (300 $\mathrm{mg}$ loading dose, $75 \mathrm{mg}$ daily thereafter) for prevention of cardiovascular events in 525patients with CTO undergoing PCI.

Results: The rate of in-hospital major adverse cardiac and cerebral events (MACCE) was not different between the groups. At 1-year follow-up, target vessel revascularization (TVR) in both ticagrelor groups were significantly lower than that in the clopidogrel group ( $p=0.047)$; TVR was significantly decreased in $60 \mathrm{mg}$ ticagrelor compared to standard dose clopidogrel $(p=0.046)$. At 1-year follow-up, overall MACCE in both ticagrelor groups were significantly lower than that in the clopidogrel group ( $p=0.023$ ). Kaplan-Meier analysis showed MACCE-free survival was significantly higher in both ticagrelor groups than in the clopidogrel group $(p=0.024)$. During hospitalization, minor bleeding was significant increased in the $90 \mathrm{mg}$ ticagrelor group $(p=0.021)$. At 1-year follow-up, risk of major and minor bleeding were significantly increased in the $90 \mathrm{mg}$ ticagrelor group.
\end{abstract}

Conclusion: In East Asian patients with CTO undergoing PCl, $60 \mathrm{mg}$ ticagrelor was as effective as $90 \mathrm{mg}$, at the same time significantly reduced risk of bleeding.

Keywords: Ticagrelor, Clopidogrel, Chronic total occlusion, Percutaneous coronary intervention

\footnotetext{
* Correspondence: 1758624242@qq.com; luanbo2016@163.com

Department of Cardiology, The People's Hospital of China Medical University,

The People's Hospital of Liaoning Province, No. 33, Wenyi road, Shenhe

District, Shenyang City, Liaoning Province, China
}

(c) The Author(s). 2020 Open Access This article is distributed under the terms of the Creative Commons Attribution 4.0 International License (http://creativecommons.org/licenses/by/4.0/), which permits unrestricted use, distribution, and reproduction in any medium, provided you give appropriate credit to the original author(s) and the source, provide a link to the Creative Commons license, and indicate if changes were made. The Creative Commons Public Domain Dedication waiver (http://creativecommons.org/publicdomain/zero/1.0/) applies to the data made available in this article, unless otherwise stated. 


\section{Introduction}

CTO was defined as thrombolysis in myocardial infarction (TIMI) grade-0 flow with a duration of 3 months, documented angiographically or clinically defined [1]. From previous studies, approximately $20 \%$ of patients with coronary heart disease have at least one CTO lesion [1]. Accumulating evidence has confirmed that successful revascularization can effectively improve myocardial ischemia, relieve angina [2], improve left ventricular function [3], and improve clinical outcomes $[4,5]$ in CTO patients. However, a higher risk of CTO-PCI, a longer duration of the procedure, and a larger number of implanted stents required more intensive anticoagulation during the perioperative period. Ticagrelor is a reversible antagonist of the P2Y12 receptor with a more rapid onset and more pronounced platelet inhibition, it is widely used in dual antiplatelet therapy following PCI. Studies have shown that ticagrelor can significantly reduce the rate of the composite endpoints of cardiovascular death, myocardial infarction, and stroke compared to clopidogrel, and does not cause an increase in major bleeding events [6]. However, most of the patients included in these clinical studies were from European and American Caucasian populations. Currently, an increasing number of studies have confirmed that the risk of thrombosis and hemorrhagic disease in East Asian populations is different from those in Caucasian populations $[7,8]$. Therefore, it is important to investigate suitable doses of ticagrelor in East Asian populations.

This study sought to investigate whether low-dose ticagrelor $(120 \mathrm{mg}$ loading dose, $60 \mathrm{mg}$ twice daily thereafter) could reduce risk of bleeding events in CTO patients following $\mathrm{PCI}$, meanwhile whether the ischemic events could be increased compared to compared to standard dose of ticagrelor and $75 \mathrm{mg}$ clopidogrel, thereby providing a reference for clinical decision making.

\section{Method}

\section{Study design and patients}

In this study, patients with a confirmed diagnosis of CTO undergoing successfully PCI were retrospective selected from January 2015 to May 2018 in our hospital. Exclusion criteria: pregnant women, patients allergic to aspirin, clopidogrel,or ticagrelor; refusal of $\mathrm{PCI}$ or failure of stents implantation, patients with an indication of anticoagulants, patients with comorbidities (including coronary artery perforation, intramural hematomas and any comorbidities that may resulted in a worse prognosis), life expectancy less than 1 year, refusal to participate in the trial. A total of 541 patients were enrolled in the study, of which 16 were lost to follow-up, and eventually 525 CTO patients who successfully underwent PCI were included in the study. Of these patients, 171 received a loading dose of $180 \mathrm{mg}$ ticagrelor followed by a maintenance dose of $90 \mathrm{mg}$ twice daily, 178 received a loading dose of $120 \mathrm{mg}$ ticagrelor followed by a maintenance dose of $60 \mathrm{mg}$ twice daily, and 176 received a loading dose of $300 \mathrm{mg}$ clopidogrel followed by $75 \mathrm{mg}$ daily. All patients received a loading dose of $300 \mathrm{mg}$ aspirin followed by a daily oral dose of $100 \mathrm{mg}$ (Fig. 1).

The routine access of the procedure was radial artery, and the physician determined the access as needed. During the procedure, a standard dose of unfractionated heparin $(100 \mathrm{IU} / \mathrm{kg})$ was used for anticoagulant therapy, and $2000 \mathrm{IU}$ of unfractionated heparin was added every hour. The use of glycoprotein IIb/IIIa inhibitor (GPI) was left to the physician's discretion. The study was approved by the Institutional Review Board of the People's Hospital of Liaoning Province, and all patients signed informed consent before participation.

\section{Study end points}

The primary efficacy endpoint of the study was a composite of adverse cardiovascular events, including allcause mortality, target vessel revascularization, stent thrombosis, nonfatal myocardial infarction, and nonfatal stroke within one year of follow-up. Myocardial infarction was defined as the presence of pathological Q waves in at least two consecutive leads, or although there was no pathological $\mathrm{Q}$ wave, the markers of myocardial injury increased to more than twice the upper limit of normal value, and this increase was not related to PCI or bypass [9]. The primary safety endpoint was defined as complications associated with bleeding during the follow-up period. Bleeding was defined based on the Bleeding Academic Research Consortium criteria [10]. Minor bleeding was defined as skin bruising, subcutaneous ecchymosis, bleeding gums, nosebleed, and so on; major bleeding was defined as gastrointestinal bleeding, intracranial hemorrhage, hemoglobin decrease of $\geq 3 \mathrm{~g} / \mathrm{dL}$, significant bleeding requiring blood transfusion, and fatal bleeding.

\section{Statistical analysis}

Statistical Package for Social Sciences (SPSS) for Windows 20 (IBM SPSS Inc., Chicago, IL) was used for statistical analysis. Normally distributed continuous data are presented as mean \pm standard deviation, and those not normally distributed are shown as median (min-max). Categorical variables are shown as numbers and percentages. To compare continuous variables, the Student ttest or Mann-Whitney U test were used, and to compare categorical variables, the chi-square test and the Fisher's exact test were used in the case of sparse data. KaplanMeier graphs were used to access survival without MACCE. All tests were two sided, and $p$ values $<0.05$ was considered significant. 


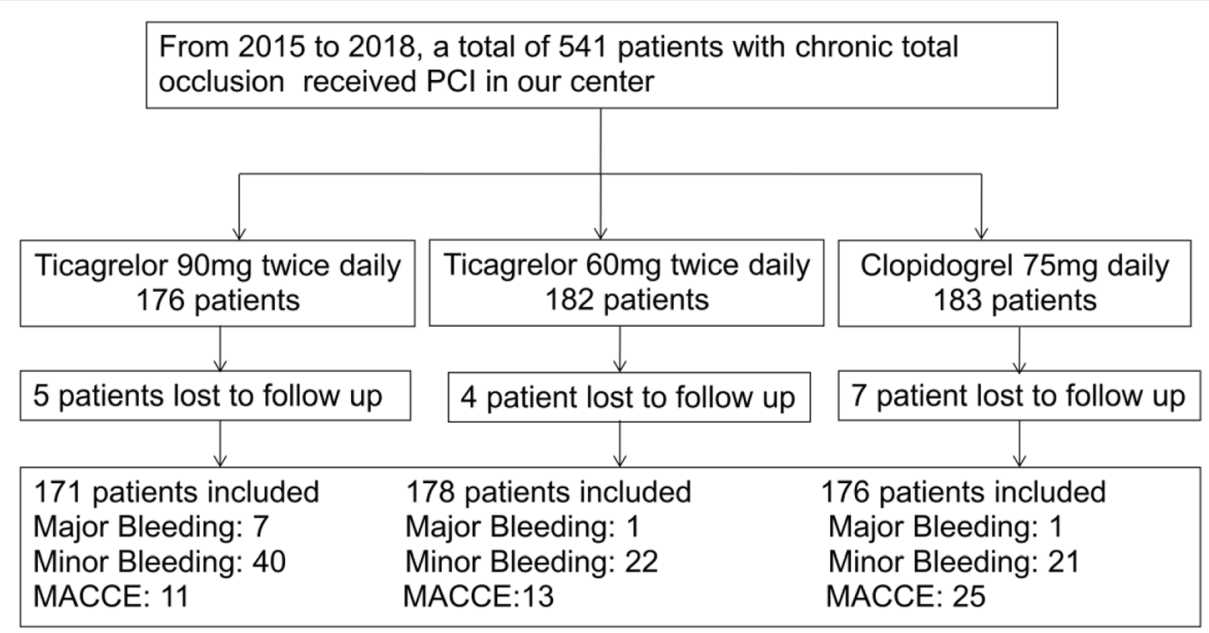

Fig. 1 Study profile

\section{Results}

In this study, 541 patients with CTO-PCI were recruited consecutively from January 2015 to May 2018 at our hospital. All the procedures were performed by one physician (corresponding author: Bo Luan). All the patients received guideline based optimal medical therapy. The follow-up endpoint was
May 2019. 16 patients were lost to follow-up, and in the end 525 CTO patients who successfully underwent coronary interventional therapy were included in the study (Fig. 1). The baseline and procedural characteristics were not statistically different among the three groups and the medication used were comparable between the groups (Tables 1 and 2).

Table 1 Clinical characteristics of study population

\begin{tabular}{|c|c|c|c|c|}
\hline Variables & Ticagrelor 90 mg $(n=171)$ & Ticagrelor $60 \mathrm{mg}(n=178)$ & Clopidogrel 75 mg $(n=176)$ & $P$-value \\
\hline Age (years) & $63.5 \pm 7.4$ & $65.3 \pm 8.2$ & $64.9 \pm 7.1$ & 0.469 \\
\hline Gender (female), n(\%) & $62(36.3 \%)$ & $68(38.2 \%)$ & $67(40.3 \%)$ & 0.741 \\
\hline Body mass index $\left(\mathrm{Kg} / \mathrm{m}^{2}\right)$ & $23.8 \pm 3.4$ & $23.5 \pm 3.8$ & $24.2 \pm 3.9$ & 0.869 \\
\hline Diabetes Mellitus, n(\%) & $52(30.4 \%)$ & $58(32.6 \%)$ & $56(31.8 \%)$ & 0.910 \\
\hline Hypertension, n(\%) & $92(53.8 \%)$ & $85(47.8 \%)$ & $82(46.6 \%)$ & 0.363 \\
\hline Current smoker, n(\%) & $69(40.4 \%)$ & $75(42.1 \%)$ & $72(40.9 \%)$ & 0.937 \\
\hline Previous Ml, n(\%) & $82(48.0 \%)$ & $80(44.9 \%)$ & $78(44.3 \%)$ & 0.772 \\
\hline Previous ischemic CVA, n(\%) & $39(22.8 \%)$ & $45(25.3 \%)$ & $38(21.6 \%)$ & 0.710 \\
\hline Previous Gl bleeding, n(\%) & $7(4.1 \%)$ & $8(4.5 \%)$ & $5(2.8 \%)$ & 0.716 \\
\hline Peptic Ulcer, n(\%) & $21(12.3 \%)$ & $25(14.0 \%)$ & $24(13.6 \%)$ & 0.886 \\
\hline LVEF(\%) & $43.2 \pm 5.5$ & $44.4 \pm 6.7$ & $43.9 \pm 5.8$ & 0.863 \\
\hline NYHA 2-3 on admision, n(\%) & $115(67.3 \%)$ & $109(61.2 \%)$ & $112(63.6 \%)$ & 0.499 \\
\hline $\mathrm{eGFR}, \mathrm{ml} / \mathrm{min} / 1.73 \mathrm{~mm} 2$ & $64.5 \pm 21.7$ & $65.1 \pm 21.9$ & $63.9 \pm 22.4$ & 0.782 \\
\hline CRUSADE score & $32.1 \pm 5.2$ & $33.4 \pm 5.5$ & $32.8 \pm 6.2$ & 0.792 \\
\hline \multicolumn{5}{|l|}{ Medication } \\
\hline ACEI/ARB, n(\%) & $80(46.8 \%)$ & $75(42.1 \%)$ & $82(46.6 \%)$ & 0.622 \\
\hline Beta-blockers, n(\%) & $75(43.9 \%)$ & $69(38.8 \%)$ & $78(44.3 \%)$ & 0.515 \\
\hline Statin, n(\%) & 165 (96.5\%) & 170 (95.5\%) & 166 (94.3\%) & 0.634 \\
\hline PPI, n(\%) & 166 (97.1\%) & $174(97.8 \%)$ & 170 (96.6\%) & 0.807 \\
\hline
\end{tabular}

Abbreviations: MI, myocardial infarction; CVA, cerebrovascular accident; GI, gastrointestinal; LVEF, left ventricular ejection fraction; NYHA, New York Heart Association; eGFR, estimated glomerular filtration rate; ACEls, angiotensin-converting enzyme inhibitors; ARBs, angiotensin receptor blockers; PPI, proton pump inhibitor 
Table 2 Procedure-related characteristics of the studied patients

\begin{tabular}{|c|c|c|c|c|}
\hline Variables & Ticagrelor 90 mg $(n=171)$ & Ticagrelor 60 mg $(n=178)$ & Clopidogrel 75 mg $(n=176)$ & $P$-value \\
\hline \multicolumn{5}{|l|}{ Site of access } \\
\hline Radial & $58(33.9 \%)$ & $52(29.2 \%)$ & $54(30.7 \%)$ & 0.627 \\
\hline Femoral & $23(13.5 \%)$ & $41(23.0 \%)$ & 35 (19.9\%) & 0.067 \\
\hline Radial and Femoral & $90(52.6 \%)$ & $85(47.8 \%)$ & $87(49.4 \%)$ & 0.657 \\
\hline Total amount of conrrast (ml) & $233.8 \pm 102.0$ & $228.3 \pm 98.6$ & $215.8 \pm 94.6$ & 0.327 \\
\hline Total time of procedure (min) & $123.6 \pm 55.9$ & $119.8 .1 \pm 57.5$ & $128.4 \pm 64.3$ & 0.621 \\
\hline LAD occlusion, n (\%) & $60(35.1 \%)$ & 55 (30.9\%) & $58(33.0 \%)$ & 0.716 \\
\hline LCX occlusion, n (\%) & $32(18.7 \%)$ & $29(16.3 \%)$ & $28(15.9 \%)$ & 0.766 \\
\hline RCA occlusion, n (\%) & $89(52.0 \%)$ & $96(53.9 \%)$ & $92(52.3 \%)$ & 0.939 \\
\hline Occlusion lesion length, mm & $58.4 \pm 26.3$ & $55.9 \pm 24.6$ & $56.6 \pm 25.4$ & 0.748 \\
\hline Retrograde filling $>$ grade 2 & $85(49.7 \%)$ & $82(46.1 \%)$ & $81(46.0 \%)$ & 0.730 \\
\hline Reverse wire technique & $44(25.7 \%)$ & $51(28.7 \%)$ & $48(27.3 \%)$ & 0.827 \\
\hline IABP, $n(\%)$ & $12(7.0 \%)$ & $9(5.1 \%)$ & $11(6.3 \%)$ & 0.743 \\
\hline IVUS, n(\%) & $34(19.9 \%)$ & $38(21.3 \%)$ & $36(20.5 \%)$ & 0.953 \\
\hline Number of stents per patient & $2.8 \pm 1.9$ & $2.6 \pm 1.8$ & $2.7 \pm 2.0$ & 0.568 \\
\hline Stent length (mean, mm) & $65.9 \pm 26.3$ & $66.4 \pm 29.5$ & $67.2 \pm 31.4$ & 0.382 \\
\hline TIMI III flow after PCI & $152(88.9 \%)$ & $162(91.0 \%)$ & $158(89.8 \%)$ & 0.814 \\
\hline Glycoprotein Ilb/llla receptor inhibitor, n(\%) & $46(26.9 \%)$ & $55(30.9 \%)$ & $52(29.5 \%)$ & 0.716 \\
\hline LMWH, (\%) & $50(29.2 \%)$ & $48(27.0 \%)$ & $56(31.8 \%)$ & 0.611 \\
\hline
\end{tabular}

Abbreviations: $L A D$ Left anterior descending artery, $L C X$ Left circumflex coronary artery, RCA Right coronary artery IABP, Intra-aortic balloon pump, IVUS

Intravascular ultrasonography, TIMI Thrombolysis in myocardial infarction, LMWH Low-molecular-weight heparin

\section{Efficacy endpoint events}

There was no difference in the rate of in-hospital major adverse cardiac and cerebral events (MACCE) between the studied groups. However, at 1-year follow-up, target vessel revascularization (TVR) in the two ticagrelor dose groups were significantly lower than that in the clopidogrel group ( $2.8 \%$ vs. $2.3 \%$ vs. $7.4 \%, p=0.047)$. TVR in 60 mg ticagrelor group was similar with $90 \mathrm{mg}$ grous $(2.3 \%$ vs. $2.8 \%, p=1.00$ ) and was significantly lower compared to the standard dose of clopidogrel $(2.8 \%$ vs. $7.4 \%, p=$ 0.046). At 1-year follow-up, the overall MACCE of the two ticagrelor dose groups were significantly lower than that of the clopidogrel group $(7.3 \%$ vs. $6.4 \%$ vs. $14.2 \%$, $p=0.023$ ). MACCE in $60 \mathrm{mg}$ ticagrelor group was

Table 3 MACCE of In-Hospital and 12-Months Follow-Up

\begin{tabular}{|c|c|c|c|c|}
\hline Variables & Ticagrelor $90 \mathrm{mg}(n=171)$ & Ticagrelor $60 \mathrm{mg}(n=178)$ & Clopidogrel 75 mg $(n=176)$ & $P$-value \\
\hline \multicolumn{5}{|l|}{ MACE in hospital } \\
\hline All-cause mortality, n(\%) & $1(0.6 \%)$ & $1(0.6 \%)$ & $2(1.1 \%)$ & 0.848 \\
\hline$M I, n(\%)$ & $2(1.2 \%)$ & $1(0.6 \%)$ & $2(1.1 \%)$ & 0.749 \\
\hline Stent thrombosis, $\mathrm{n}(\%)$ & $1(0.6 \%)$ & $2(1.1 \%)$ & $4(2.3 \%)$ & 0.465 \\
\hline Stroke, $n(\%)$ & $1(0.6 \%)$ & $1(0.6 \%)$ & $1(0.6 \%)$ & 1 \\
\hline TVR, n(\%) & $3(1.8 \%)$ & $2(1.1 \%)$ & $7(4.0 \%)$ & 0.213 \\
\hline Overall MACCE, n(\%) & $5(2.9 \%)$ & $5(2.8 \%)$ & $9(5.1 \%)$ & 0.454 \\
\hline \multicolumn{5}{|c|}{ MACE during 12-month follow-up } \\
\hline All-cause mortality, n(\%) & $2(1.2 \%)$ & $1(0.6 \%)$ & $2(1.1 \%)$ & 0.749 \\
\hline $\mathrm{Ml}, \mathrm{n}(\%)$ & $2(1.2 \%)$ & $3(1.7 \%)$ & $5(2.8 \%)$ & 0.576 \\
\hline Stent thrombosis, n(\%) & $4(2.3 \%)$ & $4(2.2 \%)$ & $6(3.4 \%)$ & 0.792 \\
\hline Stroke, $n(\%)$ & $1(0.6 \%)$ & 0 & $1(0.6 \%)$ & 0.551 \\
\hline TVR, n(\%) & $4(2.3 \%)$ & $5(2.8 \%)$ & $13(7.4 \%)$ & 0.047 \\
\hline Overall MACCE, n(\%) & $11(6.4 \%)$ & $13(7.3 \%)$ & 25 (14.2\%) & 0.023 \\
\hline
\end{tabular}

Abbreviations: MACCE Major adverse cardiac and cerebral events, TVR Target vessel revascularization, MI Myocardial infarction 
similar with $90 \mathrm{mg}$ ticagrelor groups $(7.3 \% \mathrm{vs} .6 .4 \%, p=$ 0.748 ) and was significantly decreased compared to the standard dose of clopidogrel ( $7.3 \%$ vs. $14.2 \%, p=0.036)$ (Table 3). Kaplan-Meier analysis showed that MACCEfree survival was significantly higher in ticagrelor groups than in the $75 \mathrm{mg}$ clopidogrel group $(p=0.024)$, MACCE-free survival was significantly higher in the 90 $\mathrm{mg}$ ticagrelor group compared to the clopidogrel group $(p=0.020)$, MACCE-free survival was significantly higher in the $60 \mathrm{mg}$ ticagrelor group compared to the clopidogrel group $(p=0.037)$, and there was no significant difference between the $60 \mathrm{mg}$ and $90 \mathrm{mg}$ ticagrelor groups ( $p=0.762)$ (Fig. 2).

\section{Safety endpoint events}

During hospitalization, there was a significant increase in the risk of minor bleeding in the $90 \mathrm{mg}$ ticagrelor group $(18.1 \%$ vs. $10.1 \%$ vs. $9.1 \%, p=0.021)$, although no increased risk of major bleeding was observed. The risk of minor bleeding in the $60 \mathrm{mg}$ ticagrelor group was significantly lower than in the $90 \mathrm{mg}$ ticagrelor group $(10.1 \%$ vs. $18.1 \%, p=0.044)$ and similar to that of the clopidogrel group $(10.1 \%$ vs. $9.1 \%, p=0.857)$. At the 1 year follow-up, the risk of major bleeding $(4.1 \%$ vs. $0.6 \%$ vs. $0.6 \%, p=0.016)$ and minor bleeding $(23.4 \%$ vs. $12.4 \%$ vs. $11.9 \%, p=0.004)$ were significantly higher in the 90 $\mathrm{mg}$ ticagrelor group. The risk of major bleeding $(0.6 \%$ vs. $4.1 \%, p=0.034)$ and minor bleeding $(12.4 \%$ vs. $23.4 \%$, $p=0.007$ ) were significantly lower in the $60 \mathrm{mg}$ ticagrelor group than in the $90 \mathrm{mg}$ ticagrelor group. There was no significant difference in the risk of major bleeding $(0.6 \%$ vs. $0.6 \%, p=1.000)$ or minor bleeding $(12.4 \%$ vs. $11.9 \%, p=1.000$ ) between the $60 \mathrm{mg}$ ticagrelor group and the clopidogrel group (Table 4).

\section{Discussion}

This is the first study to investigate the efficacy and safety of a low-dose ticagrelor (60 mg twice daily) antiplatelet regimen in East Asian patients with CTO undergoing PCI. We found that low-dose ticagrelor achieved similar effect in reducing the risk of revascularization and overall MACCE compared to $90 \mathrm{mg}$ group with a significant lower risk of major and minor bleeding events.

A higher risk of CTO-PCI, a longer duration of the procedure, and a larger number of implanted stents required more intensive anticoagulation during the perioperative period. However, the optimal antiplatelet therapy after CTO-PCI is still unclear. In 2014 we found that $90 \mathrm{mg}$ ticagrelor for CTO-PCI resulted in a significant bleeding events in asian patients and $75 \mathrm{mg}$ clopidogrel resulted in a significant ischemic events, at that time, we assumed that a low dose ticagrelor may be an alternative. So we start our study in 2015. Ticagrelor 60
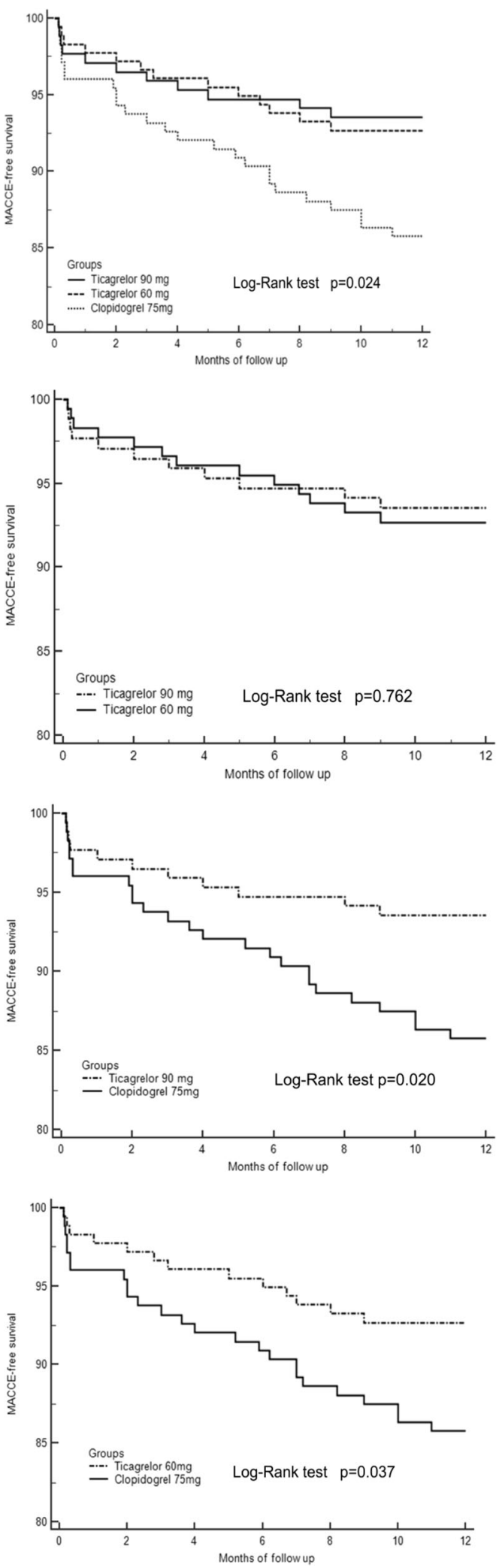

Fig. 2 Cumulative MACCE-free survival 
Table 4 Bleeding events of In-Hospital and 12-Months Follow-Up

\begin{tabular}{lllll}
\hline Variables & Ticagrelor $90 \mathrm{mg}(n=171)$ & Ticagrelor $60 \mathrm{mg}(n=178)$ & Clopidogrel $75 \mathrm{mg}(n=176)$ & \\
\hline Bleedings in hospital & & & $1(0.6 \%)$ & $16(9.1 \%)$ \\
Major bleeding, $\mathrm{n}(\%)$ & $2(1.2 \%)$ & $1(0.6 \%)$ & & 0.699 \\
Minor bleeding, $\mathrm{n}(\%)$ & $31(18.1 \%)$ & $18(10.1 \%)$ & $1(0.6 \%)$ & $\mathbf{0 . 0 2 1}$ \\
$\begin{array}{l}\text { Bleedings during 12-month follow-up } \\
\text { Major bleeding, } \mathrm{n}(\%)\end{array}$ & $7(4.1 \%)$ & $1(0.6 \%)$ & $21(11.9 \%)$ & $\mathbf{0 . 0 1 6}$ \\
Minor bleeding, $\mathrm{n}(\%)$ & $40(23.4)$ & $22(12.4 \%)$ & $\mathbf{0 . 0 0 4}$ \\
\hline
\end{tabular}

mg tablet was on market in China since March 2018. Before that, we use 2/3 of $90 \mathrm{mg}$, after March 2018, $60 \mathrm{mg}$ is available. In this study, we retrospectively analyse a low dose of ticagrelor $(120 \mathrm{mg}$ loading dose, $60 \mathrm{mg}$ twice daily thereafter) for prevention of cardiovascular events in 525 patients with CTO undergoing PCI.

A growing body of evidence has shown that ticagrelor can significantly reduce the rate of the composite end points of cardiovascular death, myocardial infarction, and stroke compared to clopidogrel, and does not cause an increase in major bleeding events [6]. However, most of the patients included in these clinical studies were from European and American Caucasian populations. Currently, an increasing number of studies have confirmed that the risk of thrombosis and hemorrhagic disease in East Asian populations is different from those in Caucasian populations [7, 8]. During antithrombotic treatment, East Asian patients tended to have a lower risk of ischemic events especially in coronary artery disease and a higher incidence of bleeding $[7,8]$. Some researchers suggested that East Asian patients have a lower risk of ischemic events after PCI despite a lower response to clopidogrel [11-13]. In addition, studies have shown that East Asian populations have significantly increased risk of gastrointestinal bleeding even with low-intensity antiplatelet therapy (such as low-dose aspirin) compared to Caucasians [14]. Therefore, it is important to investigate suitable doses of ticagrelor in East Asian populations.

The GEMINI-ACS-1 randomized study confirmed that Asia Pacific patients with acute coronary syndrome had significantly more clinically significant bleeding events during antithrombotic therapy compared to other regions [15]. A study from South Korea showed that patients prescribed $90 \mathrm{mg}$ ticagrelor had a $40.6 \%$ risk of bleeding in one month follow up [16]. Studies have confirmed that the presence of ticagrelor and its major active metabolite (ARC124910XX) is significantly higher in East Asian population than in the Caucasian population $[17,18]$. Therefore, a low dose of ticagrelor in the East Asian population can achieve a similar rate of platelet inhibition while reducing the risks of bleeding. In the sub-study of the PEGASUS-TIMI 54 study, post-dose plasma level of ticagrelor was $38 \%$ lower with $60 \mathrm{mg}$ than with $90 \mathrm{mg}$, but levels of platelet reactivity in both doses did not differ [19]. Similarly, low-dose ticagrelor (60 mg twice daily) and standard-dose ticagrelor $(90 \mathrm{mg}$ twice daily) exhibited similar 30-day rates of platelet inhibition in East Asian ACS patients [20].

A crossover study including Chinese patients with stable coronary artery disease evaluated the antiplatelet effect of very low-dose of ticagrelor ( $22.5 \mathrm{mg}$ twice daily) vs. standard-dose of clopidogrel ( $75 \mathrm{mg}$ daily) for 7 days. They found that the level of platelet reactivity in the ticagrelor group was significantly lower than that in the clopidogrel group [21]. Thus, we have reason to believe that low doses of ticagrelor are more suitable for the Asian population. We sought to investigate the efficacy and safety of low-dose $(60 \mathrm{mg})$ ticagrelor in antiplatelet therapy of CTO patients following PCI. Similar to previous studies, low-dose ticagrelor could significantly reduce composite MACCE compared to standard dose of clopidogrel. In addition, the associated risks of bleeding, including major and minor bleeding, were significantly reduced compared to the $90 \mathrm{mg}$ dose. To some extent, this indicates that low doses of ticagrelor are effective and safe in the Asian population.

In clinical practice, it is of vital inportanct to assess the ischemic and bleeding risk for the individual, since antiplatelet therapy plays pivotal role in patients with CTO-PCI. The GRACE and CRUSADE score are widely recommended for the ischemic events and bleeding risk classification, respectively. For patients at high risk of bleeding, we speculate that low-dose ticagrelor is superior to standard-dose clopidogrel. In this study, subgroup analysis was not performed due to sample size limitations, which may lead to some bias in the results.

Although this study investigated the efficacy and safety of low-dose ticagrelor antiplatelet therapy following successful PCI in East Asian CTO patients, the following limitations exist: (1) The present study did not conduct measurements of cytochrome P450 2C19 gene, which is critical for clopidogrel metabolism; (2) The present study is a single-center retrospective analysis with a small sample size, which may lead to research bias, (3) Because of the small sample size, no subgroup analysis was performed. Thus, a large-sample, multi-center, prospective 
randomized controlled trial is needed in the future to validate our conclusions.

\section{Conclusion}

In conclusion, our data suggest that In East Asian patients with CTO undergoing PCI, $60 \mathrm{mg}$ ticagrelor was as effective as $90 \mathrm{mg}$, at the same time significantly reduced risk of bleeding.

\section{Abbreviations}

CTO: Coronary chronic total occlusion; GPI: Glycoprotein Ilb/Illa inhibitor; MACCE: Major adverse cardiac and cerebral events; PCl: Percutaneous coronary intervention; TIMI: Thrombolysis in myocardial infarction; TVR: Target vessel revascularization

\section{Acknowledgements}

Not Applicable.

\begin{abstract}
Authors' contributions
Dr. YW, HWZ and Professor AJH acquired the data, performed statistical analyses, and drafted the manuscript. Professor BL, Dr. CFW, XJZ, and JT conceived the study, participated in its design and coordination, helped to draft the manuscript, and revised the manuscript critically for important intellectual content. Dr. CSC, Dr. QKM, Dr. YZ and DFL revised the manuscript critically for important intellectual content. All authors contributed to the study design and data interpretation, and all authors read and approved the final manuscript.
\end{abstract}

\section{Funding}

None.

\section{Availability of data and materials}

The datasets generated and analysed during the current study are not publicly available due to a further study of this area but are available from the corresponding author on reasonable request.

\section{Ethics approval and consent to participate}

The study had already been approved by Ethics Committee of the People's Hospital of China Medical University and all subjects provided their informed, written consent before participation.

\section{Consent for publication}

Not applicable.

\section{Competing interests}

The authors declare that they have no competing interests.

Received: 2 October 2019 Accepted: 11 December 2019

\section{1.}

\section{References}

1. Stone GW, Kandzari DE, Mehran R, Colombo A, Schwartz RS, Bailey S, Moussa I, Teirstein PS, Dangas G, Baim DS, Selmon M, Strauss BH, Tamai H, Suzuki T, Mitsudo K, Katoh O, Cox DA, Hoye A, Mintz GS, Grube E, Cannon LA, Reifart NJ, Reisman M, Abizaid A, Moses JW, Leon MB, Serruys PW. Percutaneous recanalization of chronically occluded coronary arteries: a consensus document: part I. Circ. 2005;112(15):2364-72.

2. Rossello X, Pujadas S, Serra A, Bajo E, Carreras F, Barros A, Cinca J, Pons-Lladó G, Vaquerizo B. Assessment of inducible myocardial ischemia, quality of life, and functional status after successful percutaneous revascularization in patients with chronic Total coronary occlusion. Am J Cardiol. 2016;117(5):720-6.

3. Hoebers LP, Claessen BE, Elias J, Dangas GD, Mehran R, Henriques JP. Metaanalysis on the impact of percutaneous coronary intervention of chronic total occlusions on left ventricular function and clinical outcome. Int J Cardiol. 2015;187:90-6.

4. Tomasello SD, Boukhris M, Giubilato S, Marzà F, Garbo R, Contegiacomo G, Marzocchi A, Niccoli G, Gagnor A, Varbella F, Desideri A, Rubartelli P, Cioppa A, Baralis G, Galassi AR. Management strategies in patients affected by chronic total occlusions: results from the Italian registry of chronic Total occlusions. Eur Heart J. 2015;36(45):3189-98.
5. Hoye A, van Domburg RT, Sonnenschein K, Serruys PW. Percutaneous coronary intervention for chronic total occlusions: the Thoraxcenter experience 1992-2002. Eur Heart J. 2005;26(24):2630-6.

6. Wallentin L, Becker RC, Budaj A, Cannon CP, Emanuelsson H, Held C, Horrow J, Husted S, James S, Katus H, Mahaffey KW, Scirica BM, Skene A, Steg PG, Storey RF. Harrington RA; PLATO investigators. Ticagrelor versus Clopidogrel in patients with acute coronary syndromes. N. Eng. J. Med. 2009;361 (11):1045-57.

7. Levine, Jeong GN, Goto Y-H, Anderson S, Huo JL, Mega Y, Taubert JL, Smith K, Sidney C. Expert consensus document: World Heart Federation expert consensus statement on antiplatelet therapy in East Asian patients with ACS or undergoing PCI. Nat. Rev. Cardiol. 2014;11:597-606.

8. Jeong YH. "East Asian paradox": challenge for the current antiplatelet strategy of "one-guideline-fits-all races" in acute coronary syndrome. Curr. Cardiol. Rep. 2014;16(5):485.

9. Thygesen K, Alpert JS, White HD, Jaffe AS, Apple FS, Galvani M, Katus HA, Newby LK, Ravkilde J, Chaitman B, Clemmensen PM, Dellborg M, Hod H, Porela P, Underwood R, Bax JJ, Beller GA, Bonow R, Van der Wall EE, Bassand JP, Wijns W, Ferguson TB, Steg PG, Uretsky BF, Williams DO, Armstrong PW, Antman EM, Fox KA, Hamm CW, Ohman EM, Simoons ML, Poole-Wilson PA, Gurfinkel EP, Lopez-Sendon JL, Pais P, Mendis S, Zhu JR, Wallentin LC, Fernandez-Aviles F, Fox KM, Parkhomenko AN, Priori SG, Tendera M, Voipio-Pulkki LM, Vahanian A, Camm AJ, De Caterina R, Dean V, Dickstein K, Filippatos G, Funck-Brentano C, Hellemans I, Kristensen SD, McGregor K, Sechtem U, Silber S, Widimsky P, Zamorano JL, Morais J, Brener S, Harrington R, Morrow D, Lim M, Martinez-Rios MA, Steinhubl S, Levine GN, Gibler WB, Goff D, Tubaro M, Dudek D, Al-Attar N. Universal definition of myocardial infarction. Circ. 2007;116:2634-53.

10. Choi JH, Seo JM, Lee DH, Park K, Kim YD. Clinical utility of new bleeding criteria: a prospective study of evaluation for the bleeding academic research consortium definition of bleeding in patients undergoing percutaneous coronary intervention. J Cardiol. 2015;65(4):324-9.

11. Daemen J, Wenaweser $P$, Tsuchida K, Abrecht L, Vaina S, Morger C, Kukreja N, Jüni P, Sianos G, Hellige G, van Domburg RT, Hess OM, Boersma E, Meier B, Windecker S, Serruys PW. Early and late coronary stent thrombosis of sirolimuseluting and paclitaxel-eluting stents in routine clinical practice: data from a large two-institutional cohort study. Lancet. 2007;369(9562):667-78.

12. Kimura T, Morimoto T, Nakagawa Y, Tamura T, Kadota K, Yasumoto H, Nishikawa H, Hiasa Y, Muramatsu T, Meguro T, Inoue N, Honda H, Hayashi Y, Miyazaki S, Oshima S, Honda T, Shiode N, Namura M, Sone T, Nobuyoshi M, Kita T. Mitsudo K; j-Cypher Registry Investigators.. Antiplatelet therapy and stent thrombosis after sirolimus-eluting stent implantation. Circ. 2009;119(7):987-95.

13. Park DW, Yun SC, Lee SW, Kim YH, Lee CW, Hong MK, Cheong SS, Kim JJ, Park SW, Park SJ. Stent thrombosis, clinical events, and influence of prolonged clopidogrel use after placement of drug-eluting stent data from an observational cohort study of drug-eluting versus bare-metal stents. JACC Cardiovasc Interv. 2010;1(5):494-503.

14. Ma C. Current antithrombotic treatment in East Asia: some perspectives on anticoagulation and antiplatelet therapy. Thromb Haemost. 2012;107(6): 1014-8.

15. Ohman EM, Roe MT, Steg PG, James SK, Povsic TJ, White J, Rockhold F, Plotnikov A, Mundl H, Strony J, Sun X, Husted S, Tendera M, Montalescot G, Bahit MC, Ardissino D, Bueno H, Claeys MJ, Nicolau JC, Cornel JH, Goto S, Kiss RG, Güray Ü, Park DW, Bode C, Welsh RC, Gibson CM. Clinically significant bleeding with low-dose rivaroxaban versus aspirin, in addition to P2Y12 inhibition, in acute coronary syndromes (GEMINI-ACS-1): a doubleblind, multicentre, randomised trial. Lancet. 2017;389(10081):1799-808,

16. Kang MG, Kim K, Bae JS, Ahn J-H, Jang JY, Park HW, Koh J-S, Park Y, Hwang S-J, Kwak CH, Hwang J-Y, JEONG Y-H. Bleeding episode predicts the occurrence of dyspnea during ticagrelor treatment in patients with acute coronary syndrome. Circ. 2017;136:A20526.

17. Li H, Butler K, Yang L, Yang Z, Teng R. Pharmacokinetics and tolerability of single and multiple doses of ticagrelor in healthy Chinese subjects: an open-label, sequential, two-cohort, single-Centre study. Clin Drug Investig. 2012;32(2):87-97.

18. Teng R, Butler K. Pharmacokinetics, pharmacodynamics, and tolerability of single and multiple doses of ticagrelor in Japanese and Caucasian volunteers. Int J Clin Pharmacol Ther. 2014;52(6):478-91.

19. Storey RF, Angiolillo DJ, Bonaca MP, Thomas MR, Judge HM, Rollini F, Franchi F, Ahsan AJ, Bhatt DL, Kuder JF, Steg PG, Cohen M, Muthusamy R, Braunwald E, Sabatine MS. Platelet inhibition with ticagrelor 60 mg versus 90 mg twice daily in the PEGASUS-TIMI 54 trial. J Am Coll Cardiol. 2016; 67(10):1145-54. 
20. Park DW, Lee PH, Jang S, Lim HS, Kang DY, Lee CH, Ahn JM, Yun SC, Park SW, Park SJ. Effect of low-dose versus standard-dose ticagrelor and clopidogrel on platelet inhibition in acute coronary syndromes. J Am Coll Cardiol. 2018;71(14):1594-5.

21. He M, Liu B, Sun D, Pan Y, Zheng W, Shi J, Zhao S, Dong X, Lu S, Li M, Han $Y$, Li Y. One-quarter standard-dose ticagrelor better than standard-dose clopidogrel in Chinese patients with stable coronary artery disease: a randomized, single-blind, crossover clinical study. Int J Cardiol. 2016;215: 209-13.

\section{Publisher's Note}

Springer Nature remains neutral with regard to jurisdictional claims in published maps and institutional affiliations.

Ready to submit your research? Choose BMC and benefit from:

- fast, convenient online submission

- thorough peer review by experienced researchers in your field

- rapid publication on acceptance

- support for research data, including large and complex data types

- gold Open Access which fosters wider collaboration and increased citations

- maximum visibility for your research: over $100 \mathrm{M}$ website views per year

At $\mathrm{BMC}$, research is always in progress.

Learn more biomedcentral.com/submissions 